\title{
IDENTIFIKASI SEKTOR UNGGULAN DI KOTA SALATIGA PERIODE 2010-2016
}

\author{
Timothy Jason Edon \\ Jurusan Ekonomi Pembangunan Fakultas Ekonomi dan Bisnis \\ Universitas Kristen Satya Wacana \\ e-mail:Timothyedon95@gmail.com
}

\begin{abstract}
Abstrak
Penelitian ini bertujuan untuk mengkaji potensi ekonomi di Salatiga guna mempercepat pertumbuhan ekonomi Salatiga, mengidentifikasi dan menentukan sektor unggulan di Kota Salatiga untuk meningkatkan potensi ekonomi daerah. Alat analisis yang digunakan dalam penelitian meliputi analisis Location Quotient (LQ), analisis Shift-Share, dan Indeks Spesialisasi. Hasil dari perhitungan analisis LQ menunjukkan sektor penyediaan akomodasi dan makan minum dan jasa perusahaan menempatin urutan teratas diantara 12 sektor unggulan yang didapat. Hasil analisis Indeks Spesialisasi didapatkan nilai IS mendekati nol tiap tahunnya. Yang berarti peranan tiap sektor di Kota Salatiga cenderung merata. Berdasarkan hasil analisis Shift Share didapatkan sektor indutri pengolahan dan disusul sektor kontruksi di posisi kedua. Hal ini menandakan bahwa sektor industri pengolahan mampu memberikan konstribusi terbesar bagi PDRB Kota Salatiga. Sehingga dapat dikatakan tidak terjadi pergeseran struktur ekonomi di Kota Salatiga.
\end{abstract}

Kata kunci : Sektor unggulan, LQ, Shift Share, Indeks Spesialisasi, Salatiga

\begin{abstract}
This study aims to examine the economic potential in Salatiga in order to accelerate economic growth in Salatiga, identify and determine the leading sectors in the City of Salatiga to increase the regional economic potential. The analytical tools used in the study include Location Quotient (LQ) analysis, Shift-Share analysis, and Specialization Index. The results of the LQ analysis calculations show that the sector providing accommodation and food and beverage and service companies places the top of the 12 leading sectors obtained. The results of the Specialization Index analysis show that the IS value is close to zero each year. Which means the role of each sector in Salatiga City tends to be equitable. Based on the results of the Shift Share analysis obtained the processing industry sector and followed by the construction sector in the second position. This indicates that the manufacturing sector is able to provide the largest contribution to the Salatiga City GRDP. So that it can be said that there is no shift in the economic structure in the City of Salatiga.
\end{abstract}

Keywords : Leading sectors, LQ, Shift Share, Specialization Index, Salatiga 


\section{PENDAHULUAN}

Setiap wilayah memiliki potensi ekonomi yang berbeda-beda yang dapat dikarenakan karakteristik wilayah yang berbeda-beda pula. Untuk melakukan pengembangan potensi ekonomi daerah pemerintah perlu mengetahui apa saja sumber daya yang dimiliki oleh daerah tersebut. Bila sumber daya yang ada melimpah maka proses pengembangan potensi ekonomi akan berjalan lebih cepat. Sama halnya ketika sumber daya yang ada sedikit maka proses pengembangan potensi ekonomi akan berjalan lambat. Maka dari pada itu perlu untuk mengetahui komoditas unggulan dan juga lapangan usaha basis dari daerah tersebut agar pemerintah dalam perencanaan pembangunan tidak salah strategi dan dapat mengatur daerahnya sesuai perundang-undangan yang berlaku.

Lapangan usaha unggulan itu memiliki keunggulan komparatif yang tentunya dapat diunggulkan dengan lapangan usaha dari wilayah lain. Hal ini tentu akan menguntungkan bagi suatu daerah bila memiliki lebih dari satu komoditas unggulan. Keunggulan komparatif tersebut kemudian akan menjadi keunggulan kompetitif bila bersaing dengan lapangan usaha unggulan yang sama dari daerah lain. Hal ini akan menentukan atau menciptakan kekuatan daya saing lapangan usaha dari tiap-tiap wilayah.

Percepatan pembangunan ekonomi tentunya diperlukan strategi yang tepat untuk melakukan pengembangan komoditas unggulan dari masing-masing daerah. Hal ini dikarenakan dalam pelaksanaan pembangunan ekonomi nasional tidak dapat lepas dari pembangunan ekonomi daerah. Pembangunan ekonomi daerah sendiri itu berarti proses saat pemerintah daerah dan masyarakat dalam daerah tersebut secara bersama mengelola sumber daya yang terdapat dalam daerah tersebut agar dapat menciptakan lapangan pekerjaan dan dapat menstimulus terjadinya pertumbuhan kegiatan ekonomi di daerah tersebut (Arsyad, 1999).

Hubungan antara pengembangan lapangan usaha unggulan dengan pertumbuhan ekonomi dapat dilihat ketika barang atau jasa yang dihasilkan oleh daerah tersebut bertambah jumlah permintaannya dari daerah lain. Usaha-usaha di daerah tersebut akan berkembang beriringan dengan pengembangan lapangan usaha unggulan. Selanjutnya lapangan pekerjaan akan bertambah, kemudian berdampak pada bertambahnya penghasilan daerah.

Dalam penerapannya di pembangunan Kota Salatiga maka diperlukan penentuan komoditas unggulan di Kabupaten Salatiga guna percepatan proses pembangunan. Berdasar pada data PDRB Kota Salatiga menurut lapangan usaha, Kota Salatiga unggul pada sektor industri pengolahan. Maka perlu pengkajian lebih jauh pada lapangan usaha tersebut guna pencapaian sasaran dalam pembangunan yang akan dijadikan sebagai salah satu acuan dalam menetapkan kebijakan daerah.

Pengembangan lapangan usaha unggulan daerah tentu akan membuat daerah tersebut tetap ada dan dapat bertahan dalam menghadapi perkembangan ekonomi. Maka daripada itu pengembangan lapangan usaha unggulan menjadi sangat penting bagi tiap-tiap daerah. Berdasar dari sisi sektoral saja Kota Salatiga memiliki karakteristik dan kondisi wilayah yang berbeda dengan kota-kota lainnya.

Rata-rata pertumbuhan PDRB sektoral Kota Salatiga dari tahun 2010-2016 terbesar terjadi pada sektor industri pengolahan. Meskipun konstribusi PDRB dari sektor lainnya terlibat, namun laju pertumbuhannya perlu dicari tahu sebesar apa.

Berdasar dari penelitian yang dilakukan oleh Nilatul Husna, dkk (2013) mendapat hasil bahwa lapangan usaha potensial yang ada di Kabupaten Gersik adalah lapangan usaha industri pengolahan; listrik, gas, dan air bersih; serta lapangan usaha pertambangan dan penggalian. Sedangkan RPJPD dan RPJMD pemerintah Kabupaten Garut cenderung memprioritaskan pada lapangan -lapangan usaha yang kurang potensial seperti perdagangan, hotel, dan restoran.

Maxthasen Tampilang, dkk (2015) mengungkapkan bahwa tidak ada lapangan usaha yang masuk dalam klasifikasi lapangan usaha yang maju dan tumbuh cepat. Juga dari analisis Shift Share didapat hasil bahwa kesembilan lapangan usaha mengalami pertumbuhan dari tahun ke tahun walau tidak memiliki nilai yang konstan. Diperoleh dari analisis Location Quotient bahwa lapangan usaha pertanian merupakan lapangan usaha basis.

Dudu Sudarya, dkk (2013) mengungkapkan bahwa tingkat keragaman dan keberimbangan lapangan usaha ekonomi di kecamatan wilayah pesisir masih rendah jika dibandingkan dengan tingkat perkembangan sebesar $72 \%$ dari total kemampuan maksimumnya. Maka perlunya peran pemerintah untuk melakukan pengembangan dan pemerataan ekonomi, memprioritaskan pembangunan pada Kecamatan Mekarmukti, Pakenjeng dan Caringni. Prioritas lapangan 
usaha ekonomi yang diarahkan untuk mengutamakan lapangan usaha pertanian, lapangan usaha industri pengolahan, lapangan usaha perdagangan, lapangan usaha hotel dan restoran, lapangan usaha gas, listrik dan air minum.

Kamarudin (2015) mengungkapkan bahwa lapangan usaha pertanian lebih potensial sebagai lapangan usaha basis sedangkan lapangan usaha pertambangan dan penggalian, lapangan usaha keuangan, persewaan dan jasa-jasa sebagai lapangan usaha ekonomi pendukung lapangan usaha basis. Maka daripada itu pemerintah hendaknya tetap mempertahankan lapangan usaha pertanian karena lapangan usaha ini merupakan lapangan usaha prioritas dan memberikan kontibusi yang paling besar terhadap PDRB Kabupaten Jember.

Yolamalinda (2014) mengungkapkan bahwa lapangan usaha yang paling potensial dikembangkan merupakan lapangan usaha industri pengolahan; listrik, gas dan air bersih; lapangan usaha pertambangan dan penggalian, namun pemerintah Agam lebih berprioritas pada lapangan usaha yang kurang potensial seperti perdagangan, hotel dan restoran; serta pertanian.

Nuraini Emi (2013) mengatakan bahwa lapangan usaha basis yang mendominasi perekonomian kota Mojokerto adalah lapangan usaha listrik, gas, dan air bersih; lapangan usaha perdagangan; hotel dan restoran; lapangan usaha pengangkutan dan komunikasi; lapangan usaha keuangan, persewaan dan jasa perusahaan; serta lapangan usaha jasa-jasa. Sedangkan lapangan usaha yang menjadi lapangan usaha non basis kota Mojokerto adalah lapangan usaha pertanian, lapangan usaha pertambangan dan penggalian; lapangan usaha industri pengolahan serta lapangan usaha bangunan dan konstruksi.

Dari penelitian-penelitian tersebut dapat disimpulkan bahwa adanya hasil yang berbeda-beda dikarenakan karena data PDRB yang diperoleh berbeda dari tiap daerah yang pernah diteliti sebelumnya. Maka dari pada itu penulis hendak meneliti di Kota Salatiga, karena Kota Salatiga memiliki karakteristik yang berbeda dari daerah yang pernah diteliti sebelumnya. Penelitian ini akan digunakan untuk mengetahui potensi dari sektor yang Kota Salatiga miliki dan juga akan melihat bagaimana peranan tiap sektor di Kota Salatiga, apakah sektor yang diunggulkan untuk dikembangkan sesuai dengan hasil penelitian.
Sektor unggulan dapat diartikan sebagai perbandingan antara suatu sektor di suatu daerah dengan sektor yang sama di daerah lain. Suatu sektor dapat dikatakan unggul jika sektor tersebut terbukti dapat bersaing dengan sektor dari daerah lain baik secara nasional maupun domestik (Tambunan, 2001). Maka daripada itu dapat disimpulkan bahwa sektor unggulan adalah sektor suatu daerah yang dapat bersaing dengan sektor dari daerah lain.

Dalam penentuan sektor unggulan, besar kaitannya dengan data Produk Domestik Regional Bruto (PDRB) daerah setempat. Sebab melalui data tersebut dapat dilihat kontribusi masing-masing sektor dan pertumbuhan ekonomi daerah tersebut.

Teori-teori perubahan struktural berfokus pada mekanisme yang dapat memungkinkan negara-negara terbelakang untuk merubah struktur perekonomian dalam negeri mereka dari perekonomian subsisten tradisional yang hanya mampu memenuhi kebutuhan sendiri ke perekonomian yang lebih modern, lebih berorientasi ke kehidupan perkotaan, dan lebih bervariasi, serta memiliki jasa-jasa yang tangguh, dan sektor industri manufaktur (Todaro, 2000)

Salah satu hal yang dapat dijadikan indikator tingkat pertumbuhan ekonomi adalah nilai dari Produk Domestik Regional Bruto (PDRB). Menurut Badan Pusat Statistik (2018) PDRB merupakan jumlah nilai tambah yang dihasilkan oleh seluruh unit produksi dalam suatu wilayah tertentu atau merupakan jumlah nilai barang dan jasa akhir yang dihasilkan oleh seluruh unit ekonomi.

\section{METODE}

Penelitian ini dilakukan di Kabupaten Salatiga dalam periode tujuh tahun yaitu dari tahun 2010 hingga tahun 2016 dengan obyek penelitian yang berfokus pada sektor unggulan dan pergeseran pangsa sektor-sektor ekonomi Kabupaten Salatiga. Terdapat tiga analisis yang digunakan untuk menjawab permasalahan yang telah diambil, diantaranya adalah analisis Location Quotient (LQ), Indeks Spesialisasi, dan analisis Shift Share Analisis (SSA). Seluruh data yang ada dalam penelitian ini diperoleh dengan menggunakan data primer dan data sekunder yang bersumber dari Badan Pusat Statistik (BPS) Kota Salatiga dan PDRB kota Salatiga serta PDRB Kabupaten Semarang.

Analisis LQ berguna untuk mengetahui sektor basis ataupun yang bukan menjadi basis dari suatu daerah. LQ dapat diartikan sebagai indikator sederhana yang dapat menunjukan kekuatan atau besar kecilnya 
peranan suatu sektor dalam suatu daerah dibandingkan dengan daerah di atasnya atau wilayah referensi. Dalam penerapannya metode ini dapat dilakukan dengan dua pendekatan, yaitu dengan pendekatan nilai tambah atau Produk Domestik Regional Bruto (PDRB) atau pendekatan Tenaga Kerja. Analisis LQ berguna untuk mengetahui lapangan usaha basis atau lapangan usaha unggulan suatu wilayah (Emilia, 2006).

Untuk menghitung LQ dapat dilakukan dengan cara berikut :

\section{$L Q=(P i j / P j) / P i r / P r$}

Keterangan :

Pij = PDRB Lapangan usaha i di Kota Salatiga pada tahun tertentu.

$\mathrm{Pj}=$ Total PDRB Lapangan usaha $\mathrm{i}$ di Kabupaten Semarang pada tahun tertentu.

Pir = PDRB Lapangan usaha i di Kota Salatiga pada tahun tertentu.

$\operatorname{Pr}=$ Total PDRB Lapangan usaha i di Kabupaten Semarang pada tahun tertentu.

Ketika hasil perhitungan LQ telah diperoleh barulah dapat diinterpertasikan sebagai berikut :

a. Jika $L Q>1$ maka lapangan usaha tersebut termasuk dalam kategori lapangan usaha basis yang dapat menjadi kekuatan bagi daerah untuk memperluas ekspor ke luar daerah.

b. Jika $L Q=1$ berarti tingkat spesialisasi lapangan usaha tersebut sama dengan spesialisasi di tingkat yang lebih di atas. Dapat juga berarti produk yang diproduksi di daerah tersebut hanya cukup untuk dikonsumsi bagi daerah tersebut.

c. Jika $L Q<1$ berarti wilayah yang lebih rendah memiliki tingkat spesialisasi yang lebih rendah dari wilayah yang lebih di atas, dikategorikan sebgai lapangan usaha non basis.

\section{Indeks Spesialisasi}

Analisis ini merupakan salah satu cara untuk mengukur perilaku kegiatan ekonomi secara keseluruhan. Misal ketika akan menghitung bagaimana Pendapatan Domestik Regional Bruto (PDRB) di suatu wilayah tersebar. Adapun cara menghitungnya sebagai berikut:

a. Hitung jumlah presentase PDRB suatu lapangan usaha terhadap totalnya.

b. Hitung jumlah presentase PDRB suatu lapangan usaha terhadap totalnya untuk wilayah yang lebih atas.

c. Hitung selisih antara presentase yang diperoleh dari tahap a dan b kemudian jumlahkan nilai-nilai selisih yang bertanda positif, lalu total nilai tersebut dan dibagi 100 untuk mendapatkan nilai IS.

Semakin besar IS maka akan semakin tinggi tingkat spesialisasi lapangan usaha di wilayah tersebut yang terkonsentrasi pada lapangan usaha yang mempunyai nilai selisih presentase positif.

Analisis Shift-Share merupakan teknikteknik dalam menganalisis perubahan struktur ekonomi daerah dibandingkan dengan perekonomian nasional. Tujuan analisis ini adalah untuk menentukan kinerja atau produktivitas kerja perekonomian daerah dengan daerah yang lebih besar (regional atau nasional) (Arsyad, 2010).

Pada prinsipnya SSA berusaha untuk memecah atau mendekomposisi besaran selisih antara nilai tambah pada tahun ke-t dengan nilai tambah pada tahun dasar, biasanya dinotasikan dengan $\left(\Delta \mathrm{Y}_{\mathrm{i}}\right)$. Ada tiga variabel yang menjadi komponen dari deviasi $\Delta \mathrm{Y}_{\mathrm{i}}$, yaitu komponen pertumbuhan ekonomi regional (PR), komponen pertumbuhan proporsional $(\mathrm{PP})$, komponen pertumbuhan pangsa wilayah (PPW).

$$
\Delta Y_{i,=} P R+P P+P P W
$$

Adapun hasil yang dapat disimpulkan adalah:

1. Pertumbuhan Regional

Jika PR bernilai positif maka pertumbuhan wilayah tersebut lebih cepat dibandingkan pertumbuhan nasional rata-rata. Sedangkan jika PR bernilai negatif maka berarti bahwa pertumbuhan regional wilayah tersebut lebih rendah dari pertumbuhan nasional rata-rata.

\section{Pertumbuhan Proporsional}

Jika PP bernilai positif maka ada indikasi bahwa lapangan usaha ke-i merupakan lapangan usaha yang maju, lapangan usaha tersebut tumbuh lebih cepat jika dibandingkan dengan lapangan usaha ekonomi secara keseluruhan. Jika bernilai negatif maka lapangan usaha tersebut merupakan lapangan usaha yang lamban.

3. Pertumbuhan Pangsa Wilayah

PPW ini menunjukan daya saing yang dimiliki suatu lapangan usaha ke-i di suatu 
wilayah dibandingkan dengan lapangan usaha yang sama pada wilayah pembanding (wilayah di atasnya).

\section{HASIL DAN PEMBAHASAN}

Data yang diperoleh dalam penelitian adalah data tentang keterampilan menulis naskah drama berbahasa bali pada kelompok

Kota Salatiga terletak di tengah-tengah wilayah Kabupaten Semarang. Terletak antara $007^{\circ} .17^{\prime}$ dan $007^{\circ} .17^{\prime} .23^{\prime \prime}$ Lintang Selatan dan antara $110^{\circ} .27^{\prime} .56,81^{\prime \prime}$ dan $110^{\circ} .32 .4,64^{\prime \prime}$ Bujur Timur. Luas wilayah Kota Salatiga pada tahun 2016 tercatat sebesar $56,781 \mathrm{~km} 2$. Luas yang ada, terdiri dari $7,779 \mathrm{~km} 2(13,73 \%)$ lahan sawah dan 48,982 km2 (86,27\%) bukan lahan sawah.

Secara administratif Kota Salatiga terbagi menjadi 4 kecamatan dan 23 kelurahan. Keempat kecamatan tersebut adalah Kecamatan Sidorejo yang terdiri dari 6 kelurahan yakni Blotongan, Sidorejo Lor, Salatiga, Bugel, Kauman Kidul, dan Pulutan. Kecamatan Tingkir yang terdiri dari 7 kelurahan yakni Kutowinangun Kidul, Gendongan, Sidorejo Kidul, Kalibening, Tingkir Lor, dan Tingkir Tengah. Kecamatan siswa yang mengikuti pembelajaran menggunakan media film pendek dan kelompok siswa yang mengikuti pembelajaran dengan pendekatan konvensional. Rincian data tentang keterampilan menulis naskah drama berbahasa bali diperoleh deskripsi data secara umum sebagai berikut.

Argomulyo yang terdiri dari 6 kelurahan yakni Noborejo, Ledok, Tegalrejo, Kumpulrejo, Randuacir, dan Cebongan. Kecamatan Sidomukti yang terdiri dari 4 kelurahan yakni Kecandran, Dukuh, Mangunsari, dan Kalicacing.

Analisis LQ berguna untuk mengetahui sektor basis ataupun yang bukan menjadi basis dari suatu daerah. LQ dapat diartikan juga sebagai indikator sederhana yang dapat menunjukan kekuatan atau besar kecilnya peranan suatu sektor dalam suatu daerah dibandingkan dengan daerah di atasnya atau wilayah referensi. Analisis LQ berguna untuk mengetahui lapangan usaha basis atau lapangan usaha unggulan suatu wilayah. (Emilia, 2006).

Tabel 1. Hasil Analisis LQ dan IS Kota Salatiga

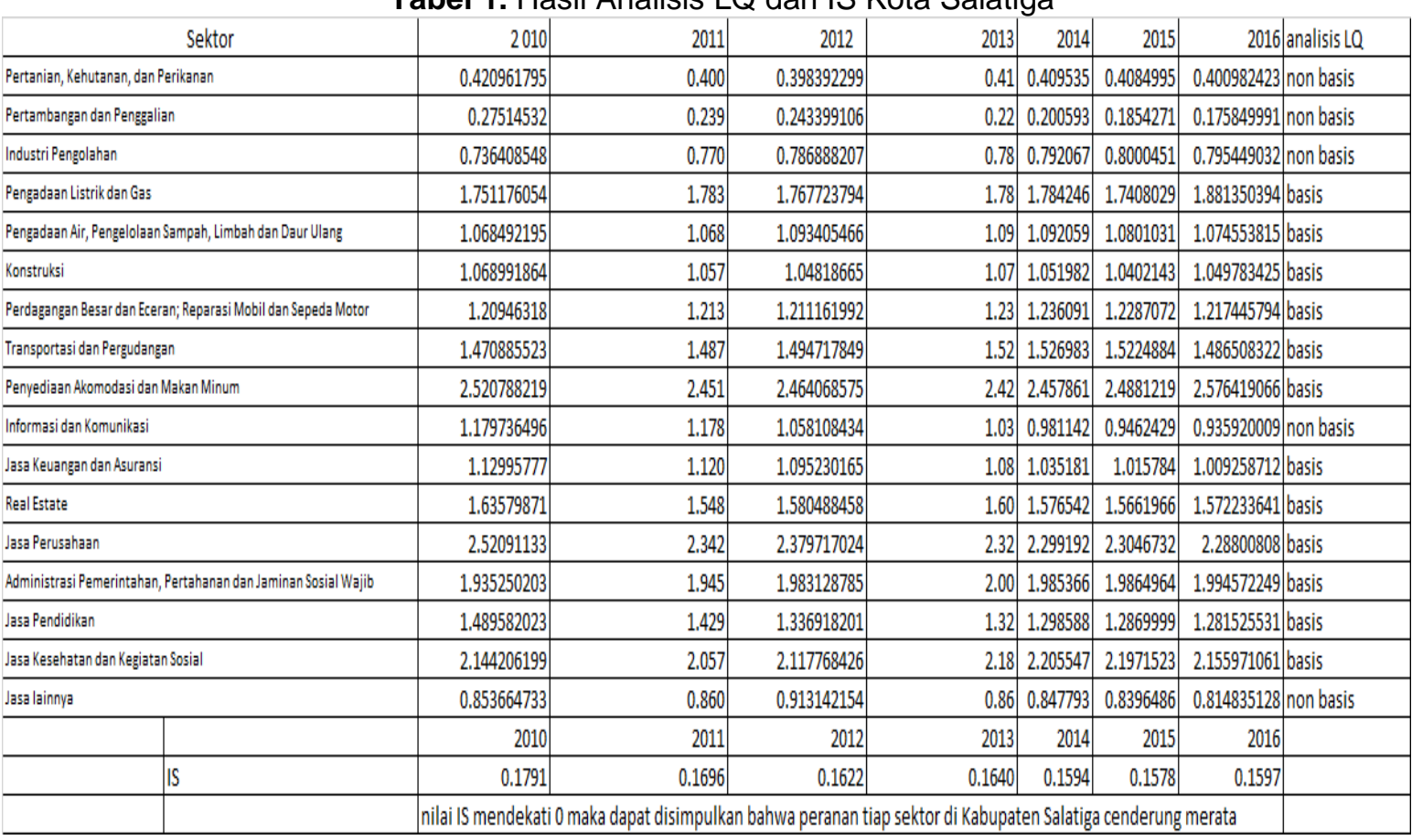

Berdasarkan hasil perhitungan LQ pada tabel, Kabupaten Salatiga dari tahun 2010 hingga tahun 2016 memiliki 12 sektor yang dapat dijadikan sektor unggulan diantaranya adalah sektor pengadaan listrik dan gas, sektor pengadaan air pengelolaan sampah limbah dan daur ulang, sektor kontruksi, sektor perdagangan, sektor transportasi dan pergudangan, sektor penyediaan akomodasi dan makan minum, sektor jasa keuangan dan asuransi, sektor real estate, sektor jasa perusahaan, sektor administrasi pemerintahan pertahanan dan jaminan sosial wajib, sektor jasa pendidikan, dan sektor jasa kesehatan 
dan kegiatan sosial. Hasil dari perhitungan analisis LQ menunjukkan sektor penyediaan akomodasi dan makan minum dan jasa perusahaan menempatin urutan teratas diantara 12 sektor unggulan yang didapat.

Kedua belas sektor ini bisa dijadikan sektor unggulan karena memiliki nilai LQ yang lebih dari 1. Nilai LQ lebih dari 1 berarti bahwa kedua belas sektor tersebut di Kabupaten Salatiga memiliki peranan yang lebih besar dibandingkan dengan peranan sektor yang sama dibandingkan Semarang.

Kelima sektor lainnya seperti sektor pertanian kehutanan dan perikanan, sektor pertambangan dan penggalian, sektor industri pengolahan, sektor informasi dan komunikasi, dan sektor jasa lainnya tidak dapat dijadikan sektor unggulan di Salatiga. Hal ini dikarenakan nilai LQ dari kelima sektor tersebut kurang dari 1. Nilai LQ kurang dari 1 berarti bahwa kelima sektor tersebut di Salatiga memiliki peranan yang lebih kecil dibandingkan dengan peranan sektor yang sama di Semarang.

\section{Hasil Analisis Indeks Spesialisasi}

Analisis indeks spesialisasi merupakan salah satu cara untuk mengukur perilaku kegiatan ekonomi secara keseluruhan. Semakin besar IS maka akan semakin tinggi tingkat spesialisasi lapangan usaha di wilayah tersebut yang terkonsentrasi pada lapangan usaha yang mempunyai nilai selisih presentase positif.

Berdasarkan hasil perhitungan didapatkan nilai IS mendekati nol tiap tahunnya, maka dapat disimpulkan bahwa peranan tiap sektor di Kota Salatiga cenderung merata.

\section{Hasil Analisis Shift Share}

Analisis Shift Share digunakan untuk mengetahui proses pertumbuhan ekonomi Kota Salatiga dikaitkan dengan perekonomian Kabupaten Semarang. Analisis Shift Share dalam penelitian ini menggunakan variabel pendapatan, yaitu PDRB untuk menguraikan pertumbuhan ekonomi Kota Salatiga. Perubahan nilai tambah sektor tertentu dalam PDRB Kota Salatiga merupakan penjumlahan dari Pertumbuhan Regional (PR), Pertumbuhan Proposional (PP), dan Pertumbuhan Pangsa Wilayah (PPW).

Tabel 2. Hasil Perhitungan Nilai Shift Share Kota Salatiga

\begin{tabular}{|l|r|r|r|r|r|r|}
\hline \multirow{2}{*}{ Sektor } & \multicolumn{5}{c}{ Hasil Analisis Shift Share PR } \\
\cline { 2 - 7 } & $2010-2011$ & $2011-2012$ & $2012-2013$ & $2013-2014$ & $2014-2015$ & $2015-2016$ \\
\hline Pertanian, Kehutanan, dan Perikanan & 43235 & 45586 & 48668 & 54585 & 59363 & 65477 \\
\hline Pertambangan dan Penggalian & 633 & 598 & 582 & 545 & 591 & 648 \\
\hline Industri Pengolahan & 214033 & 259315 & 299571 & 326565 & 371001 & 407602 \\
\hline Pengadaan Listrik dan Gas & 1829 & 1904 & 2019 & 2064 & 2222 & 2327 \\
\hline Pengadaan Air, Pengelolaan Sampah, Limbah dan Daur Ulang & 844 & 868 & 849 & 875 & 911 & 943 \\
\hline Konstruksi & 113139 & 121743 & 132560 & 149253 & 165768 & 181375 \\
\hline Perdagangan Besar dan Eceran; Reparasi Mobil dan Sepeda Motor & 116592 & 132365 & 136471 & 148719 & 158437 & 169999 \\
\hline Transportasi dan Pergudangan & 24228 & 25390 & 27138 & 30197 & 35021 & 39922 \\
\hline Penyediaan Akomodasi dan Makan Minum & 60058 & 66441 & 71294 & 75746 & 86536 & 97437 \\
\hline Informasi dan Komunikasi & 29884 & 32955 & 32541 & 34133 & 35719 & 36945 \\
\hline Jasa Keuangan dan Asuransi & 28858 & 31877 & 35804 & 38618 & 40482 & 44435 \\
\hline Real Estate & 39484 & 42288 & 45504 & 49347 & 55170 & 60916 \\
\hline Jasa Perusahaan & 7695 & 8475 & 9457 & 10951 & 12154 & 13926 \\
\hline Administrasi Pemerintahan, Pertahanan dan Jaminan Sosial Wajib & 51531 & 53383 & 59500 & 62879 & 66725 & 73020 \\
\hline Jasa Pendidikan & 27172 & 35792 & 45115 & 52876 & 60415 & 65482 \\
\hline Jasa Kesehatan dan Kegiatan Sosial & 9681 & 11213 & 13611 & 15307 & 17751 & 19761 \\
\hline Jasa lainnya & 8370 & 8925 & 9354 & 9837 & 11286 & 11986 \\
\hline
\end{tabular}




\begin{tabular}{|l|r|r|r|r|r|r|}
\hline \multirow{2}{*}{ Sektor } & \multicolumn{5}{c|}{ Hasil Analisis Shift Share PP } \\
\cline { 2 - 7 } & $\mathbf{2 0 1 0 - 2 0 1 1}$ & $\mathbf{2 0 1 1 - 2 0 1 2}$ & $\mathbf{2 0 1 2}-\mathbf{2 0 1 3}$ & $\mathbf{2 0 1 3 - 2 0 1 4}$ & \multicolumn{1}{|c|}{$\mathbf{2 0 1 4 - 2 0 1 5}$} & $\mathbf{2 0 1 5}-2016$ \\
\hline Pertanian, Kehutanan, dan Perikanan & -6687.92 & -20446.67 & -14814.12 & -15183.44 & -11439.44 & -37401.06 \\
\hline Pertambangan dan Penggalian & -196.91 & -791.82 & -391.70 & 232.66 & 251.17 & -191.14 \\
\hline Industri Pengolahan & 43433.64 & 1116.47 & -55815.06 & -31068.95 & -122064.20 & -121230.4 \\
\hline Pengadaan Listrik dan Gas & -1495.19 & -882.26 & -1643.67 & -918.20 & -968.37 & -1006.95 \\
\hline Pengadaan Air, Pengelolaan Sampah, Limbah dan Daur Ulang & -648.88 & -1139.37 & -592.56 & -603.50 & -578.37 & -616.42 \\
\hline Konstruksi & -36901.75 & -29427.14 & -21658.49 & -1683.35 & -31034.40 & -72524.68 \\
\hline Perdagangan Besar dan Eceran; Reparasi Mobil dan Sepeda Motor & 695.48 & -97641.43 & -51460.64 & -81514.65 & -62000.16 & -60416.26 \\
\hline Transportasi dan Pergudangan & -17241.46 & -12863.34 & -6386.32 & 5468.12 & 3142.91 & -23790.48 \\
\hline Penyediaan Akomodasi dan Makan Minum & 3048.52 & -31660.56 & -23169.61 & -3520.26 & -12457.35 & -34498.18 \\
\hline Informasi dan Komunikasi & -5915.30 & -7858.29 & -13032.63 & -6836.51 & -15853.76 & -12748.13 \\
\hline Jasa Keuangan dan Asuransi & -3561.29 & 4270.86 & -10028.68 & -9095.60 & -3893.62 & -5145.09 \\
\hline Real Estate & 198.50 & -24408.83 & -18798.83 & 1760.00 & -8280.82 & -21880.97 \\
\hline Jasa Perusahaan & 3158.56 & -2073.56 & 4275.27 & -651.13 & 1070.09 & 1511.25 \\
\hline Administrasi Pemerintahan, Pertahanan dan Jaminan Sosial Wajib & -39026.36 & -14961.12 & -34542.21 & -29474.09 & -18929.38 & -29494.01 \\
\hline Jasa Pendidikan & 49598.15 & 58382.72 & 19961.17 & 13656.51 & -17184.90 & -10723.79 \\
\hline Jasa Kesehatan dan Kegiatan Sosial & 5561.99 & 4098.74 & -3274.24 & 1698.13 & -1858.32 & -3473.35 \\
\hline Jasa lainnya & -4602.83 & -9626.39 & -238.13 & 2067.09 & -5016.21 & -359.19 \\
\hline
\end{tabular}

Hasil Analisis Shift Share PPW

\begin{tabular}{|c|c|c|c|c|c|c|}
\hline \multirow[b]{2}{*}{ Sektor } & \multicolumn{6}{|c|}{ Hasil Analisis Shift Share PPW } \\
\hline & 2010-2011 & 2011-2012 & 2012-2013 & 2013-2014 & 2014-2015 & 2015-2016 \\
\hline Pertanian, Kehutanan, dan Perikanan & -18861 & -1966 & 10646 & -3471 & -1938 & -9975 \\
\hline Pertambangan dan Penggalian & -696 & 76 & -469 & -438 & -406 & -279 \\
\hline Industri Pengolahan & 83077 & 42314 & -40748 & 38686 & 26323 & -21845 \\
\hline Pengadaan Listrik dan Gas & 231 & -163 & -32 & 38 & -462 & 1504 \\
\hline Pengadaan Air, Pengelolaan Sampah, Limbah dan Daur Ulang & -13 & 134 & -67 & -1 & -89 & -44 \\
\hline Konstruksi & -11531 & -10972 & 14643 & -23367 & -17360 & 12394 \\
\hline Perdagangan Besar dan Eceran; Reparasi Mobil dan Sepeda Motor & 1333 & -3850 & 7106 & 5880 & -9482 & -13791 \\
\hline Transportasi dan Pergudangan & 1750 & 623 & 2256 & 610 & -1307 & -7717 \\
\hline Penyediaan Akomodasi dan Makan Minum & -15102 & 1719 & -14641 & 8920 & 7900 & 27597 \\
\hline Informasi dan Komunikasi & -876 & -28207 & -7541 & -15365 & -10650 & -3527 \\
\hline Jasa Keuangan dan Asuransi & -2595 & -6611 & -4616 & -15504 & -6858 & -2688 \\
\hline Real Estate & -18594 & 6312 & 2196 & -7320 & -3671 & 1528 \\
\hline Jasa Perusahaan & -4990 & 985 & -2493 & -1257 & 103 & -962 \\
\hline Administrasi Pemerintahan, Pertahanan dan Jaminan Sosial Wajib & 1423 & 7579 & 453 & -4478 & -455 & 1947 \\
\hline Jasa Pendidikan & -11943 & -24064 & -6708 & -9834 & -5129 & -2751 \\
\hline Jasa Kesehatan dan Kegiatan Sosial & -3721 & 2723 & 2418 & 1372 & -776 & -3216 \\
\hline lasa lainnya & 408 & 3927 & -5480 & -1012 & -1002 & -30 \\
\hline
\end{tabular}

Hasil analisis Shift Share menunjukan bahwa selama tahun 2010-2016, nilai PDRB Kota Salatiga mengalami perkembangan naik turun dan, pada tahun 2015-2016 didapatkan nilai PDRB sebesar 833.301 juta rupiah. Dari tabel diatas terlihat PR memiliki nilai positif di semua sektor, namun hanya ada 3 sektor yang memiliki nilai tinggi di tiap tahunnya dan terus bertambah. Peringkat pertama ditempati sektor industri, disusul sektor konstruksi, dan sektor perdagangan besar dan eceran. Yang artinya ketiga sektor ini pertumbuhan wilayah Kota Salatiga lebih cepat dibandingkan pertumbuhan nasional rata-rata.

Berdasarkan dari hasil tabel nilai PP dapat terlihat bahwa pada tahun 2010-2014 sektor jasa pendidikan terlihat dominan maju dibanding sektor lainnya. Namun pada tahun 2014-2016 terlihat peralihan dari sektor jasa pendidikan ke sektor jasa perusahaan. Hal ini berarti di Salatiga terjadi perubahan ekonomi dari sektor pendidikan menjadi sektor jasa perusahaan.

Jika kita lihat dari hasil PPW terlihat bahwa pada tahun 2010-2014 sektor industri pengolahan memiliki daya saing yang dominan dibanding sektor lainnya yang ada di Kota Salatiga, meskipun pada tahun 2014-2016 justru yang menjadi daya saing adalah sektor penyediaan akomodasi dan makan minum. Meski begitu sektor industri pengolahan masih memiliki nilai PRDR yang lebih tinggi tiap tahunnya dan dikatakan bisa bersaing dengan 
sektor yang sama dengan Kabupaten Semarang.

Berdasarkan hasil analisis Shift Share, dapat disimpulkan bahwa sektor industri pengolahan memiliki nilai positif yang paling besar dan disusul sektor kontruksi di posisi kedua. Hal ini menandakan bahwa sektor industri pengolahan mampu memberikan konstribusi terbesar bagi PDRB Kota Salatiga. Sehingga dapat dikatakan tidak terjadi pergeseran struktur ekonomi di Kota Salatiga.

\section{PENUTUP}

Berdasarkan hasil perhitungan, maka dapat dirangkum simpulan penelitian sebagai berikut :

Terdapat 12 sektor yang dapat dijadikan sektor unggulan basis diantaranya adalah sektor pengadaan listrik dan gas, sektor pengadaan air pengelolaan sampah limbah dan daur ulang, sektor kontruksi, sektor perdagangan, sektor transportasi dan pergudangan, sektor penyediaan akomodasi dan makan minum, sektor jasa keuangan dan asuransi, sektor real estate, sektor jasa perusahaan, sektor administrasi pemerintahan pertahanan dan jaminan sosial wajib, sektor jasa pendidikan, dan sektor jasa kesehatan dan kegiatan sosial.

Kedua belas sektor tersebut di Kabupaten Salatiga memiliki peranan yang lebih besar dibandingkan dengan peranan sektor yang sama dibandingkan Semarang.

Didapat nilai IS mendekati nol tiap tahunnya, maka dapat disimpulkan bahwa peranan tiap sektor di Kota Salatiga cenderung merata.

Berdasarkan hasil analisis Shift Share disimpulkan bahwa sektor indutri pengolahan memiliki nilai positif yang paling besar dan disusul sektor kontruksi di posisi kedua. Hal ini menandakan bahwa sektor industri pengolahan mampu memberikan konstribusi terbesar bagi PDRB Kota Salatiga. Sehingga dapat dikatakan tidak terjadi pergeseran struktur ekonomi di Kota Salatiga.

Saran untuk pemerintah Kota Salatiga agar pembangunan daerah Kota Salatiga lebih berhasil, maka pemerintah Kota Salatiga harus lebih berfokus pada sektor yang memberikan kontribusi yang besar yang dimilikinya melalui pengembangan sektor dan subsektor unggulan atau potensial.

\section{DAFTAR PUSTAKA}

Arsyad, Lincolin. 1999. Pengantar Perencanaan dan Pembangunan Ekonomi Daerah. Yogyakarta : BPFE.
Arsyad, Lincolin. 2010. Ekonomi Pembangunan. Yogyakarta : STIE YKPN.

Badan Pusat Statistik. 2018. PDRB Kota Salatiga Seri 2010 Menurut Lapangan Usaha Harga Berlaku (Juta Rupiah).

Badan Pusat Statistik. 2018. Produk Domestik Regional Bruto Kabupaten Semarang Menurut Lapangan Usaha 2010-2016. https://www.bps.go.id/subject/11/produkdomestik-bruto--lapangan-usaha.html\#subjekViewTab3 (diakses tanggal 2 Juli 2019)

Emilia, dkk. 2006. Modul Ekonomi Regional. Jambi : FE Universitas Jambi.

https://www.bps.go.id/subject/11/produkdomestik-bruto--lapangan-usaha.html\#subjekViewTab3 (diakses tanggal 2 juli 2019)

Husna, Nailatul, Irwan Noor, dan Mochammad Rozikin. 2013. Analisis Pengembangan Potensi Ekonomi Lokal Untuk Menguatkan Daya Saing Daerah Di Kabupaten Gersik. Jurnal Administrasi Publik (JAP). 01 (1), 188-196.

Kamarudin. 2015. Analisis Potensi Sektor Ekonomi Kabupaten Jember. http://jurnal.unars.ac.id/artikel/2015-0345-44-2\%20KOMARUDDIN.pdf (diakses tanggal 1 agustus 2019)

Nuraini, Emi. 2013. Analisis Sektor Potensial Di Kota Mojokerto Tahun 2007-2011. Jurnal Pendidikan Ekonomi (JUPE). 01 (3), (1-15).

Sudarya, Dudu, Santun R. P. Sitorus, dan Muhammad Firdaus. 2013. Analisis Perkembangan Ekonomi Wilayah Untuk Arahan Pembangunan Kecamatan Di Wilayah Pesisir Kabupaten Garut. Jurnal IImiah Geomatika. 19 (2), (134-140).

Tambunan, Tulus. 2001. Perekonomian Indonesia : Teori dan Temuan Empiris. Jakarta : Ghalia Indonesia. 
Tampilang, Maxthasen, Rosalina Koleangandan, dan Patrick Wauran. 2015. Analisis Potensi Perekonomian Daerah Kabupaten Kepulauan Talaud. Jurnal Berkala IImiah Efisiensi. 15 (2), (32-46).

Todaro, Michael P. 2000. Pembangunan Ekonomi di Dunia Ketiga. Jakarta : Erlangga.

Yolamalinda. 2014. Analisis Potensi Ekonomi Daerah Dalam pengembangan Komoditi Unggulan Kabupaten Agam. Journal of Economic and Economic Education. 03 (1), (27-41). 